\title{
PEMBERDAYAAN MASYARAKAT BERBASIS POTENSI LOKAL MELALUI SKEMA PERHUTANAN SOSIAL DI AREA KPH TERNATE-TIDORE
}

\author{
Abdul Kadir Kamaluddin', Mahdi Tamrin ${ }^{1}$ \\ ${ }^{1}$ Program Studi Kehutanan, Universitas Khairun, Ternate \\ email:dul_alzi@yahoo.com; adhy.nagkokotu@gmail.com \\ Manuscript recieved:15-11-2019 Revision Accepted: 30-11-2019
}

\begin{abstract}
Abstrak
Pembangunan kehutanan Indonesia dengan skema perhutanan sosial lebih menitikberatkan pada upaya pemberdayaan secara partisipatif untuk meningkatkan kemampuan masyarakat dalam mengelolah potensi sumberdaya hutan di sekitarnya. Penelitian ini bertujuan (1) menganalisis pola pengembangan ekowisata pada area perhutanan sosial di hutan desa Akebalanda Kelurahan Moya; (2) mengetahui bentuk pemberdayaan masyarakat melalui skema perhutanan sosial pada area ekowisata hutan desa Akebalanda Kelurahan Moya; dan (3) menganalisis keterlibatan stakeholder dalam membangun kemitraan untuk pengembangan ekowisata di hutan desa Akebalanda Kelurahan Moya. Metode dasar yang digunakan dalam penelitian ini adalah metode survei deskriptif dengan pendekatan beberapa teknik Participatory Rural Appraisal (PRA) seperti: pemetaan kawasan, penelusuran lokasi, sketsa area ekowisata, diagram venn dan wawancara semi terstruktur. Hasil penelitian menunjukkan bahwa pengembangan ekowisata Akebalanda Kelurahan Moya mengadopsi pola pengembangan ekowisata yang berbasis masyarakat. Pembangunan ekowisata di Kelurahan Moya merupakan bagian dari program perhutanan sosial yang berorientasi pada kegiatan pemberdayaan masyarakat yang dimaksudkan untuk mewujudkan kemandirian masyarakat untuk dapat hidup dengan baik melalui pemanfaatan potensi sumberdaya hutan berbasis lokal yang dimiliki oleh masyarakat. Pendampingan, workshop dan pelaksanaan bimbingan teknis perhutanan sosial (BIMTEK-PS) merupakan bentuk keterlibatan stakeholder untuk pengembangan perhutanan sosial di Kota Ternate dan HPHD Akebalanda secara khusus dengan melibatkan berbagai pihak, diantaranya akademisi, praktisi dan LSM serta para pihak terkait sebagai mitra pengembangan perhutanan sosial Maluku Utara dan Kota Ternate secara khusus.
\end{abstract}

Kata kunci: Pemberdayaan, Perhutanan Sosial, Ekowisata

\section{PENDAHULUAN}

Pemberdayaan masyarakat adalah sebuah konsep pembangunan ekonomi yang merangkum nilai-nilai sosial. Konsep ini menggambarkan sebuah paradigma baru dalam pembangunan, yakni yang bersifat "people centred, participatory, empowering, and sustainable" (Chambers, 1992). Menurut (Purnomo, 2013), pemberdayaan masyarakat merupakan upaya untuk meningkatkan peran serta masyarakat dan kemandirian melalui pendekatan partisipatif sehingga masyarakat memiliki kesempatan untuk mengembangkan potensi kreasi, mengontrol lingkungan dan sumberdayanya sendiri. Sementara menurut (Noor, 2011), dalam rangka untuk memberdayakan masyarakat dapat dikaji dari tiga aspek yaitu: (a). Enabling, menciptakan suasana yang memungkinkan potensi masyarakat dapat berkembang; (b). Empowering, memperkuat potensi yang dimiliki masyarakat dalam berbagai peluang yang 
akan membuat masyarakat semakin berdaya; (c). Protecting, melindungi dan membela kepentingan masyarakat lemah.

Pemberdayaan masyarakat menjadi perhatian publik dan dinilai sebagai salah satu pendekatan yang sesuai untuk mengatasi berbagai masalah sosial dan ekonomi terutama kemiskinan, yang dilaksanakan oleh berbagai elemen mulai dari pemerintah, swasta dan oraganisasi kemasyarakatan. Pemberdayaan masyarakat merupakan salah satu upaya untuk memberikan daya atau kekuatan bagi masyarakat untuk dapat keluar dari permasalahan yang dihadapinya. Menurut (Widayanti, 2012) menyatakan pemberdayaan masyarakat dimaksudkan untuk memandirikan masyarakat agar dapat menghadapi berbagai tantangan kehidupan di lingkungannya.

Permasalahan sosial, ekonomi, dan kebijakan tentunya juga akan mempengaruhi pengelolaan hutan secara berkelanjutan khususnya dalam pengembangan ekowisata. Dalam pengelolaan perhutanan sosial bukan saja masyarakat yang terlibat, namun berbagai bentuk partisipan juga ikut campur dalam pengelolaan hutan seperti pemerintah, LSM, koperasi, perbankan, perguruan tinggi dan lembaga kemasyarakatan sebagai mitra dalam pembangunan kehutanan.

Pembangunan kehutanan Indonesia dengan skema perhutanan sosial menitikberatkan pada upaya pemberdayaan secara partisipatif untuk meningkatkan kemampuan masyarakat dalam mengelola potensi sumberdaya hutan di sekitarnya. Perhutanan sosial sendiri merupakan sistem pengelolaan hutan lestari yang dilaksanakan dalam kawasan hutan negara atau hutan hak/hutan adat yang dilaksanakan oleh masyarakat setempat sebagai pelaku utama untuk meningkatkan kesejahteraannya, keseimbangan lingkungan dan dinamika sosial budaya dalam bentuk Hutan Desa, Hutan Kemasyarakatan, Hutan Tanaman Rakyat, Hutan Rakyat, Hutan Adat, dan Kemitraan Kehutanan (KLHK, 2018).

Kota Ternate memiliki beragam potensi baik potensi alam maupun potensi budaya, namun beragamnya potensi tersebut tidak banyak yang termanfaatkan oleh masyarakat. Pengembangan ekowisata bisa menjadi pilihan tambahan dengan dukungan dari berbagai pihak termasuk pemerintah dalam pengembangan ekowisata daerahnya. Selain itu, dengan adanya area ekowisata akan memungkinkan adanya perlindungan-perlindungan (pelestarian) alam karena salah satu yang ditawarkan dari adanya ekowisata adalah keasrian sebuah kawasan. Oleh karena itu, dengan perkembangan wisata ini akan diperoleh keuntungan dari segi ekonomi dan lingkungan dengan adanya sumber pendapatan baru yang bisa memberikan kontribusi dan mengubah perekonomian masyarakat serta keuntungan lainnya dari segi lingkungan, dimana dengan adanya area ekowisata akan menjadikan masyarakat selalu menjaga lingkungan dari kerusakan-kerusakan yang bisa terjadi, karena mengedepankan aspek keasrian lingkungan sebagai sebuah aksi nyata melalui ekowisata yang ditawarkan.

Adanya pengembangan ekowisata sebagai salah satu program pemberdayaan masyarakat pada skema hutan desa yang dikelola oleh Lembaga Pengelola Hutan Desa (LPHD) Akebalanda di wilayah kerja KPH Ternate-Tidore akan memberikan manfaat yang berarti bagi masyarakat setempat. Pengelolaan hutan desa oleh masyarakat di tuntut untuk tidak hanya menjual hasil panen dari hasil hutan secara langsung namun dapat memanfaatkan lahan yang dimiliki untuk dijadikan tempat wisata dengan menyediakan berbagai fasilitas yang dapat dimanfaatkan oleh wisatawan. Oleh karena itu, penelitian ini akan membahas 
tentang pemberdayaan masyarakat melaui ekowisata sebagai salah satu perwujudan pemberdayaan masyarakat pada program perhutanan sosial dengan skema Hutan Desa (HD) di Kelurahan Moya, Kota Ternate.

Penelitian ini bertujuan: (1) menganalisis pola pengembangan ekowisata pada area perhutanan sosial di hutan desa Akebalanda Kelurahan Moya, (2) mengetahui bentuk pemberdayaan masyarakat melalui skema perhutanan sosial pada area ekowisata hutan desa Akebalanda Kelurahan Moya (3) menganalisis keterlibatan stakeholder dalam membangun kemitraan untuk pengembangan ekowisata di hutan desa Akebalanda Kelurahan Moya.

\section{METODE PENELITIAN}

Penelitian ini dilaksanakan di hutan desa Akebalanda Kelurahan Moya, Kota Ternate. Pemilihan lokasi dilakukan secara sengaja atau purposive sampling dengan pertimbangan lokasi tersebut merupakan wilayah pengembangan ekowisata pada areal perhutanan sosial, Lembaga Pengelola Hutan Desa (LPHD) Akebalanda. Penelitian dilaksanakan selama tiga bulan dimulai pada bulan Juli hingga September 2019.

\section{Teknik Pengumpulan Data}

Metode dasar yang digunakan dalam penelitian ini adalah metode survei deskriptif dengan pendekatan beberapa teknik Participatory Rural Appraisal (PRA) seperti; pemetaan kawasan, penelusuran lokasi, sketsa area ekowisata, diagram venn, dan wawancara semi terstruktur.

Pengumpulan data PRA dilakukan secara langsung di kelompok masyarakat pengelola Hutan Desa Akebalanda Kelurahan Moya dengan pendekatan:

1. Observasi, dilakukan melalui pengamatan secara langsung di lapangan dengan melibatkan diri dan berinteraksi sosial dalam masyarakat.

2. Focus Group Discussion (FGD)

3. Studi literatur, yang didasarkan atas laporan-laporan hasil penelitian, jurnal-jurnal, karya ilmiah dan sebagainya. Disamping itu juga dilakukan pencatatan pada data-data sekunder yang terdapat di instansi-instansi yang ada kaitannya dengan penelitian.

\section{ANALISIS DATA}

Data dan informasi yang dikumpulkan, baik data primer maupun data sekunder, kemudian dianalisis dengan analisis deskriptif kualitatif dan kuantitatif, meliputi kondisi wilayah, letak, luas kawasan, pola pengelolaan ekowisata, kondisi pemukiman, pendidikan, pendapatan masyarakat, dan kegiatan ekonomi masyarakat dari ekowisata yang dikelola masyarakat.

\section{HASIL DAN PEMBAHASAN}

Kelurahan Moya merupakan salah satu kelurahan yang berbatasan dengan hutan lindung gunung Gamalama, termasuk dalam wilayah Kecamatan Ternate Tengah, Kota Ternate. Batasbatas kelurahan ini yakni sebelah utara berbatasan dengan Kelurahan Soa, sebelah timur berbatasan dengan Kelurahan Salahudin, sebelah selatan berbatasan dengan Kelurahan Marikrubu, dan sebelah barat berbatasan dengan hutan lindung Gamalama (BPS, 2018). 


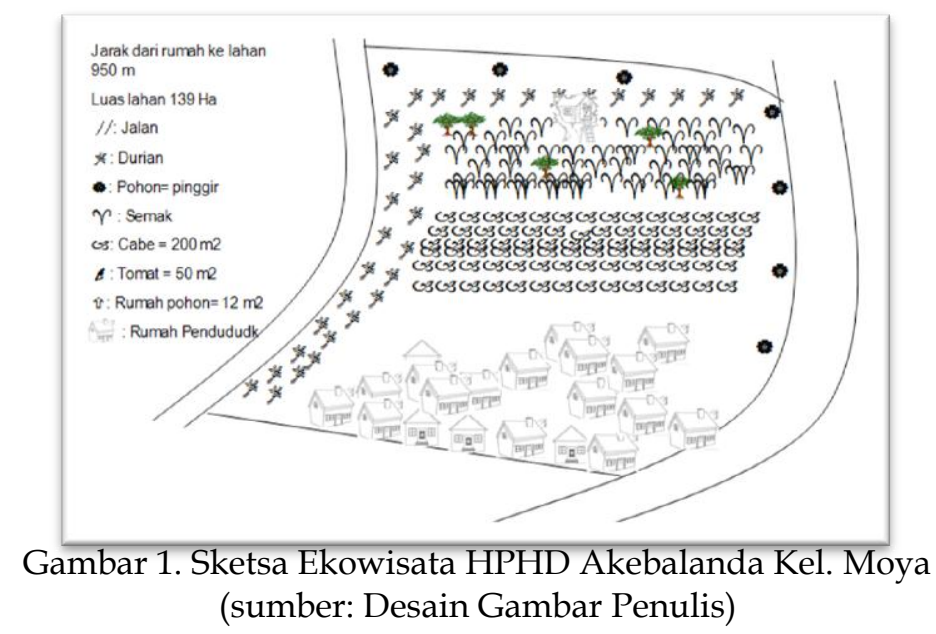

Hutan Lindung Gamalama termasuk di dalamnya Hutan Desa Akebalanda merupakan salah satu hutan lindung di Gunung Gamalama Kota Ternate yang mempunyai peranan penting dalam pengaturan tata air tanah dan perlindungan lingkungan yakni merupakan sumber mata air untuk para pendaki gunung Gamalama. Luas wilayah Hutan Desa Akebalanda secara keseluruhan adalah 139 ha. Sebagian besar wilayahnya berupa perbukitan dengan kemiringan di atas 50\%. Menurut (Rayes, 2007) menyatakan bahwa kemiringan lahan merupakan salah satu peranan penting dalam menentukan kemampuan suatu lahan. Dari luasan lahan tersebut masyarakat memanfaatkan dengan menanam berbagai jenis tanaman di antaranya adalah jenis tanaman perkebunan, pertanian, buah-buahan dan berbagai jenis tanaman sayuran.

\section{Pengembangan Ekowisata Akebalanda}

Pengembangan ekowisata Akebalanda merupakan satu bentuk pemberdayaan oleh pemerintah melalui program perhutanan sosial yang dikelola secara langsung oleh masyarakat dengan tujuan untuk meningkatkan pendapatan ekonomi kelompok pengelola secara khusus dan masyarakat secara umum dengan tetap memperhatikan aspek lingkungan. Ekowisata merupakan salah satu bentuk perluasan dari pariwisata alternatif yang timbul sebagai konsekuensi dari ketidakpuasan terhadap bentuk pariwisata yang kurang memperhatikan dampak sosial dan ekologis, namun lebih mementingkan keuntungan ekonomi dan kenyamanan manusia semata (Nugraheni, Hartomo, \& Patworo, 2002). Menurut (Lindsay, 2003) menyebutkan bahwa ekowisata muncul sebagai konsep yang menyatukan antara kepentingan pemerhati lingkungan dan ahli pembangunan. Ekowisata menekankan pentingnya konservasi ekologi tanpa meninggalkan kepentingan sosial ekonomi masyarakat lokal. Menurut (Denman, 2001) menyatakan bahwa ekowisata dikembangkan berdasarkan pada pengetahuan lokal, ekowisata mampu menyediakan pendapatan untuk masyarakat lokal, dan mendorong komunitas untuk lebih menghargai kehidupan liar di sekelilingnya, sehingga dapat memberikan manfaat bagi konservasi.

Pengembangan ekowisata Akebalanda Kelurahan Moya dilakukan dengan mengadopsi pola ekowisata yang berbasis masyarakat. Pola ini mendukung dan memungkinkan keterlibatan penuh oleh masyarakat melalui kelompok setempat dalam perencanaan, pelaksanaan, dan pengelolaan usaha ekowisata dan segala keuntungan yang diperoleh. Ekowisata berbasis masyarakat merupakan usaha ekowisata yang menitikberatkan peran aktif komunitas. Hal 
tersebut didasarkan kepada kenyataan bahwa masyarakat memiliki pengetahuan tentang alam serta budaya yang menjadi potensi dan nilai jual sebagai daya tarik wisata, sehingga pelibatan masyarakat menjadi mutlak. Pola ekowisata berbasis masyarakat mengakui hak masyarakat lokal dalam mengelola kegiatan wisata di kawasan yang mereka miliki secara adat ataupun sebagai pengelola (Ditjen, 2009).

Ekowisata berbasis masyarakat dapat menciptakan kesempatan kerja bagi masyarakat setempat, dan mengurangi kemiskinan, di mana penghasilan ekowisata adalah dari jasa-jasa wisata untuk turis, fee pemandu, ongkos transportasi, homestay, menjual kerajinan dan lainlain (Ditjen, 2009). Ekowisata membawa dampak positif terhadap pelestarian lingkungan dan budaya asli masyarakat lokal setempat yang pada akhirnya akan mampu menumbuhkan jati diri dan rasa bangga antar masyarakat atau kelompok tani hutan (KTH) yang tumbuh akibat peningkatan kegiatan ekowisata. Dengan adanya pola ekowisata berbasis masyarakat bukan berarti bahwa masyarakat akan menjalankan usaha ekowisata sendiri.

Implementasi ekowisata HPHD Akebalanda perlu dipandang sebagai bagian dari perencanaan pembangunan terpadu yang dilakukan di suatu kawasan hutan baik itu kawasan lindungn, produksi maupun kasawasan koservasi. Untuk itu, pelibatan para pihak terkait mulai dari level komunitas, masyarakat, pemerintah, dunia usaha dan organisasi non pemerintah diharapkan membangun suatu jaringan dan menjalankan suatu kemitraan yang baik sesuai peran dan keahlian masing-masing.

Beberapa aspek kunci dalam ekowisata berbasis masyarakat pada kawasan hutan adalah; (1) Masyarakat membentuk Lembaga Pengelola Hutan Desa (LPHD) untuk pengelolaan kegiatan ekowisata di wilayahnya, dengan dukungan dari pemerintah dan organisasi masyarakat (LSM maupun perguruan tinggi); (2) Prinsip local ownership yang dikembangkan (pengelolaan dan kepemilikan oleh masyarakat setempat) diterapkan sedapat mungkin terhadap sarana dan prasarana ekowisata serta kawasan ekowisata yang dibangaun oleh LPHD Akebalanda Kelurahan Moya.

\section{Pemberdayaan Masyarakat Melalui Skema Perhutanan Sosial}

Pembangunan ekowisata di Kelurahan Moya merupakan bagian dari program perhutanan sosial yang berorientasi pada kegiatan pemberdayaan masyarakat dimaksudkan untuk mewujudkan kemandirian masyarakat untuk dapat hidup dengan baik melalui pemanfaatan potensi sumberdaya hutan yang dimiliki oleh suatu masyarakat. Pemberdayaan masyarakat melalui program pembangunan ekowisata juga dimaksudkan untuk memberikan kontribusi bagi pembangunan kawasan yang baik guna melindungi kerusakan-kerusakan yang mungkin terjadi, seperti misalnya ancaman hilangnya sumber-sumber potensi budaya yang ada dimasyarakat. Menurut (Nalayani, 2016) menyatakan pemberdayaan masyarakat melalui jasa lingkungan (ekowisata) adalah suatu bentuk integrasi antara atraksi, akomodasi dan fasilitas pendukung yang disajikan dalam suatu struktur kehidupan masyarakat yang menyatu dengan alam, tata cara serta tradisi yang berlaku di masyarakat lokal.

Pembagunan ekowisata merupakan kegiatan pemberdayaan masyarakat yang memiliki maksud sebagai upaya untuk memberikan ruang serta daya kepada masyarakat. Menurut (Ramos \& Prideaux, 2014), pemberdayaan adalah proses yang menggambarkan sarana yang individu dan kelompok memperoleh kekuasaan, akses ke sumber daya dan keuntungan kontrol atas hidup mereka. Hal tersebut menggambarkan bahwa dengan adanya 
pemberdayaan masyarakat memungkinkan masyarakat dapat mandiri dengan diberikannya akses atas sumber daya lokal yang dimilik masyarakat.

Pemberdayaan bisa dikatakan sebagai sebuah proses bagaimana orang menjadi cukup kuat untuk berpartisipasi dalam berbagai kegiatan dan pengontrolan atas kebijakan yang mempengaruhi kehidupan mereka. Pemberdayaan menekankan bahwa setiap orang dapat memperoleh keterampilan, pengetahuan dan kekuasaan yang cukup untuk mempengaruhi kehidupannya, dan kehidupan orang lain. Oleh karena itu, dalam rangka melaksanakan kegiatan pemberdayaan masyarakat di HPHD Akebalanda Kelurahan Moya sebagai salah satu destinasi wisata Kota Ternate diperlukan sikap aktif dari masyarakat untuk pengembangan dan keberlanjutan.

Berdasarkan hasil yang telah dipaparkan diatas, dapat dijelaskan bahwa pemberdayaan masyarakat bisa dilihat dari beberapa sisi, hal tersebut dapat digambarkan dengan merujuk sisi pemberdayaan masyarakat yang diungkapkan oleh (Kartasasmita, 1997) sebagai berikut:

1. Menciptakan suasana atau iklim yang memungkinkan potensi masyarakat berkembang (enabling).

2. Memperkuat potensi atau daya yang dimiliki masyarakat (empowering).

3. Memberdayakan mengandung pula arti melindungi. Dalam proses pemberdayaan, harus dicegah yang lemah menjadi bertambah lemah, oleh karena kekurang berdayaan dalam menghadapi yang kuat.

Perwujudan dari beberapa poin diatas adalah masyarakat diajak untuk turut berpartisipasi aktif dalam rangka mengembangkan potensi lokal yang dimiliki oleh masyarakat dengan membangun ekowisata sebagai destinasi wisata baru di Kota Ternate.

Pengembangan ekowisata HPHD Akebalanda saat ini sedang dan telah membangun beberapa fasilitas untuk mendukung sarana dan prasana pengunjung atau wisatawan dengan membangun aksesibilitas jalan, tempat parkir, panggung selfie, rumah pohon, serta beberapa fasiltas pengujung lainnya. Selain itu dengan adanya ekowitasa tersebut masyarakat menjadi mampu dan berkembang dengan mengolah lahan sekitar lokasi ekowisata untuk menanam beberapa jenis sayuran maupun buah-buahan. Dengan demikian hasilnya dapat dijual pada setiap pengunjung yang datang menikmati keindahan alam Kota Ternate dari lokasi ekowitasa Akebalanda.
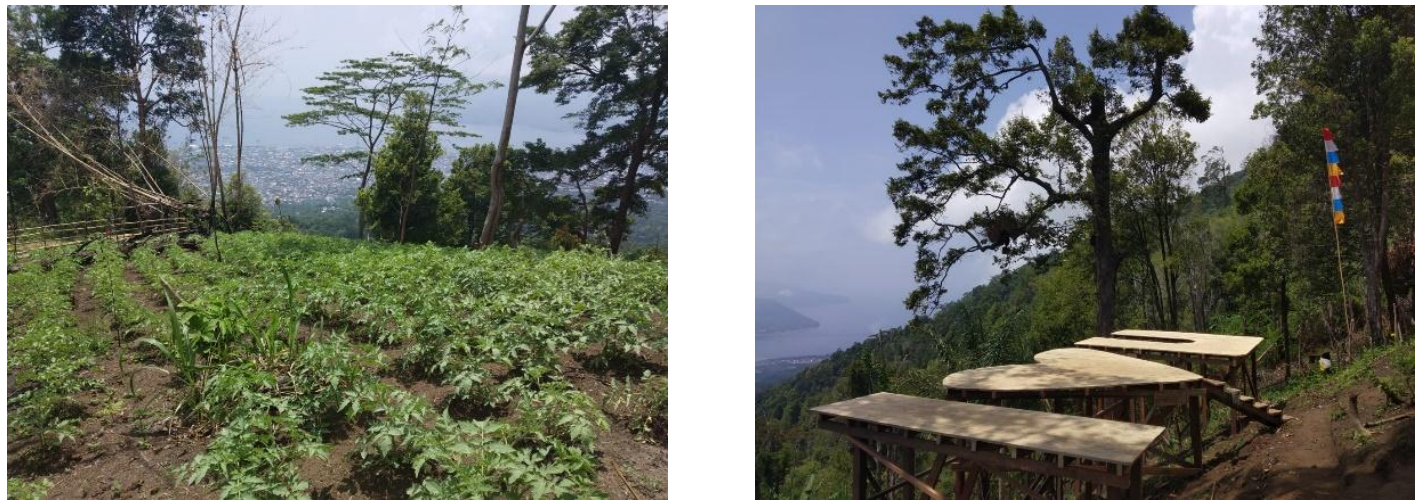

Gambar 2. Pengembangan Ekowisata Akebalanda Kelurahan Moya (sumber: Dokumentasi Penulis)

Peningkatan kemampuan merupakan tujuan dari adanya pemberdayaan masyarakat melalui pengembangan potensi lokal yang ada disekitar masyarakat. Menurut (Suryani, 2014) 
pemberdayaan merupakan proses untuk mengangkat harkat dan martabat seseorang atau kelompok masyarakat, melalui penguatan kemampuan belajar sepanjang hayat (life long learning) sebagai proses yang dapat memutakhirkan pengetahuan, kecakapan, dan kemampuan lainnya yang berguna bagi kehidupan. Dengan demikian, kehadiran lokasi ekowitasa baru tersebut masyarakat memiliki kesempatan untuk mendapat tambahan penghasilan selain penghasilan utama yaitu dalam bidang pertanian yang dikembangkan disekitar lokasi ekowisata Akebalanda.

\section{Kerjasama Kemitraan dalam Pengembangan Ekowitasa Akebalanda}

Indikator keberhasilan pengembangan usaha jasa lingkungan (ekowisata) secara umum membutuhkan keterlibatan berbagai pihak dalam memberikan kontribusi yang konstruktif dari berbagai elemen yang ada, dan harus bertanggungjawab penuh atas rencana pengembangan yang disusun bersama-sama secara berkelanjutan. Oleh karena itu, pengembangan kerjasama kemitraan dari berbagai pihak (stakeholder) merupakan poin penting untuk mencapai tujuan.

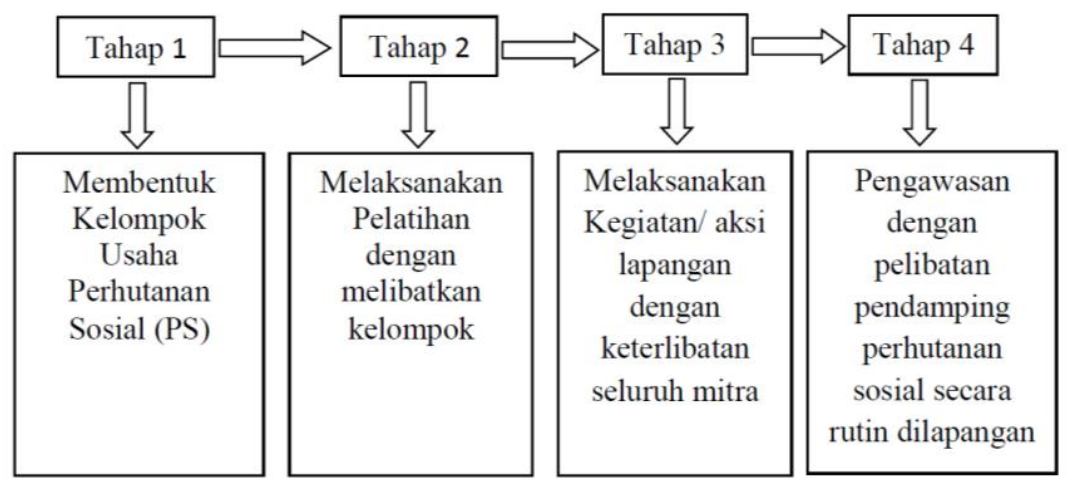

Gambar 3. Tahapan Rencana Pengembangan Pembangunan Ekowisata

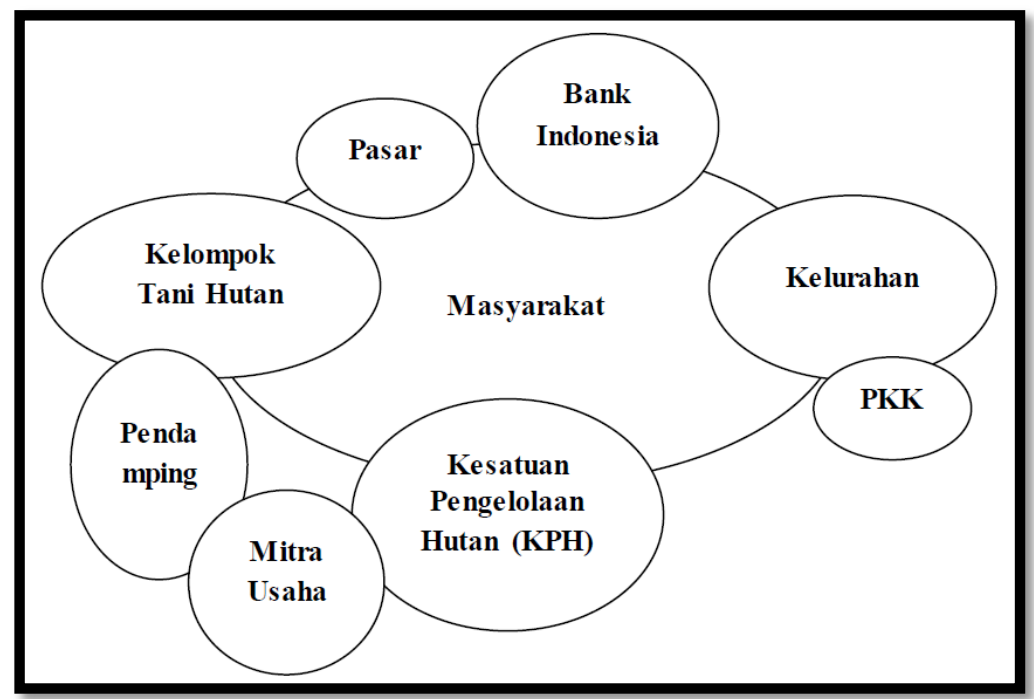

Gambar 4. Diagram VEEN Hubungan Kemitraan Pengembangan Ekowisata

Pendekatan di atas digunakan untuk penyempurnaan suatu rencana pengembangan ekowisata melalui partisipatif yang digunakan untuk pelaksanaan dan pemantauan serta evaluasi keberhasilan kegiatan pengembangan usaha jasa lingkungan melalui ekowisata. 


\section{Keterlibatan Stakeholder dalam Ekowisata Akebalanda}

Gambaran tentang keterlibatan stakeholder dalam ekowisata desa Akebalanda dijelaskan sebagai berikut:

1. Melaksanakan Pelatihan Bimbingan Teknis

Pelaksanaan Bimbingan teknis perhutanan sosial (BIMTEK-PS) dilaksanakan pemerintah yang secara teknis dilaksanakan oleh Balai Perhutanan Sosial (PSKL) Maluku-Papua dengan melibatkan berbagai pihak, diantaranya akdemisi, praktisi dan LSM serta para pihak terkait sebagai mitra pengembangan perhutanan sosial Maluku Utara dan Kota Ternate Secara khusus.

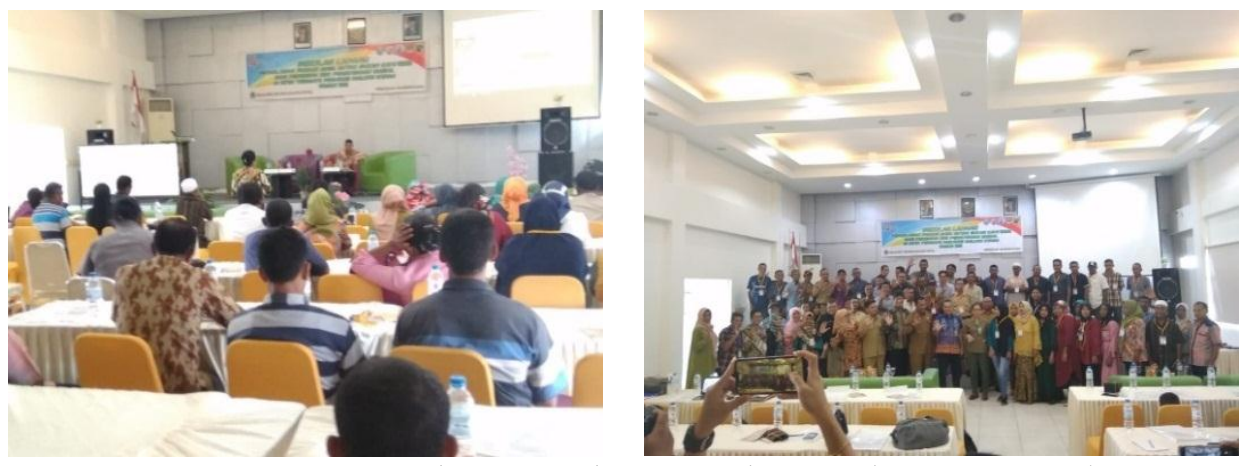

Gambar 5. Bimbingan Teknis Perhutanan Sosial

2. Pendampingan Perhutanan Sosial

Pendampingan Perhutanan Sosial merupakan kegiatan yang dilakukan bersama masyarakat secara kontinu untuk pengelolaan hutan lestari yang dilaksanakan dalam kawasan hutan negara atau hutan hak/hutan adat, sehingga masyarakat mampu mengorganisasikan dirinya maupun kelompoknya dalam mengakses informasi pasar, teknologi, pemodalan dan sumber daya lainnya sebagai upaya meningkatkan produktivitas, efisiensi usaha, pendapatan dan kesejahteraannya serta meningkatkan kesadaran dan kemandirian dalam pelestarian fungsi lingkungan hidup.

\section{Keberlanjutan Perhutanan Sosial di Maluku Utara}

Peraturan Menteri Lingkungan Hidup dan Kehutanan Nomor 83 Tahun 2016 Tentang Perhutanan Sosial merupakan bagian dari kebijakan pemerataan ekonomi untuk mengurangi ketimpangan penguasaan lahan dikalangan masyarakat. Selain itu, dengan perhutanan sosial juga dapat diatur hubungan hukum antar-warga/komunitas dengan hutan dalam upaya peningkatan mutu pengelolaan hutan lestari.

Perhutanan sosial juga mengasumsikan bahwa pihak yang paling merasakan keberhasilan atau kegagalan pengelolaan hutan adalah masyarakat di sekitar hutan. Karena itu, mereka harus mendapat insentif paling tinggi untuk mengurus usaha kehutanan sebagai sumber kehidupan sekaligus mencegah kerusakan. Perhutanan sosial juga diharapkan dapat mengurangi kemiskinan dan konflik terkait dengan akses terhadap lahan. Bagi kelompok yang tidak sepaham, perhutanan sosial dikhawatirkan lebih sebagai pembagian dan pengelolaan dibandingkan pelestarian hutan. 
Pokja PPS (2016) dalam lokakarya Percepatan Perhutanan Sosial Maluku Utara melaporkan bahwa melalui Direktorat Penyiapan Kawasan Perhutanan Sosial (PKPS)-Ditjen PSKL Maluku Utara diberikan akses pengelolaan kawasan hutan dengan penerapan lima skema perhutanan sosial. Berdasarkan SK Menteri LHK No. 4865 / 2017, Malut memiliki Peta Indikatif Areal Perhutanan Sosial (PIAPS) seluas 128.672 ha. Sementara kegiatan perhutanan yang sudah dikembangkan di Maluku Utara saat ini (2019) adalah seluas 20.750 ha, terdiri atas HKm (7.659 ha), HD (21.679 ha), HTR (19.438 ha) dan Hutan Adat (58.169,89 ha).

\section{KESIMPULAN}

1. Pengembangan ekowisata Akebalanda Kelurahan Moya mengadopsi pola pengembangan ekowisata yang berbasis masyarakat. Pola ini mendukung dan memungkinkan keterlibatan penuh oleh masyarakat melalui kelompok dalam perencanaan, pelaksanaan, dan pengelolaan usaha ekowisata dan segala keuntungan yang diperoleh.

2. Pembangunan ekowisata di Kelurahan Moya merupakan bagian dari program perhutanan sosial yang berorientasi pada kegiatan pemberdayaan masyarakat yang dimaksudkan untuk mewujudkan kemandirian masyarakat untuk dapat hidup dengan baik melalui pemanfaatan potensi sumberdaya hutan berbasis lokal yang dimiliki oleh masyarakat.

3. Pendampingan, workshop dan pelaksanaan bimbingan teknis perhutanan sosial (BIMTEK-PS) merupakan bentuk keterlibatan stakeholder untuk pengembngan perhutanan sosial di Kota Ternate dan HPHD akebalanda secara khusus dengan melibatkan berbagai pihak, diantaranya akdemisi, praktisi dan LSM serta para pihak terkait sebagai mitra pengembangan perhutanan sosial Maluku Utara dan Kota Ternate Secara khusus.

\section{SARAN}

Perhutanan sosial di Maluku Utara relatif baru, untuk itu harus menjadi perhatian khusus untuk kajian-kajian tentang pengembangan perhutanan sosial di wilaya ini. Program perhutanan sosial sudah menjadi program Nasioanl dengan menggunakan lima skema pengembangan yaitu Hutan Kemasyarakatan (HKm), Hutan Desa (HD), Hutan Tanaman Rakyat (HTR), Hutan Adat (HA) dan Kemitraan Kehutanan yang berdampak positif terhadap kemandirian masyarakat melalui kelompok-kelompok yang dibentuk.

\section{UCAPAN TERIMA KASIH}

Penelitian ini didanai oleh DIPA Unkhair 2019. Kami berterima kasih kepada Ketua Kelompok HPHD Akebalanda, kelurahan Moya Kota Ternate Tengah. Kami juga berterima kasih kepada Dr. Sri D.A.S dan Dr. Suratman Sujud atas komentar yang sangat memperbaiki naskah penelitian kami.

\section{DAFTAR PUSTAKA}

BPS, B. P. S. K. T. (2018). Kota Ternate Dalam Angka Tahun 2017. In BPS Kota Ternate.

Chambers, R. (1992). Rural apprasial: rapid, relaxed and participatory. Institute of Development Studies (UK).

Denman, R. (2001). Guidelines for community-based ecotourism development. WWF International. 
Ditjen, P.-D. (2009). Prinsip dan kriteria ekowisata berbasis masyarakat. In Kerjasama Direktorat Produk Pariwisata Direktorat Jenderal Pengembangan Destinasi Pariwisata Departemen Kebudayaan dan Pariwisata dan WWF Indonesia. Jakarta.

Kartasasmita, G. (1997). Membangun Sumber Daya Sosial Profesional. Disampaikan Pada Kongres Ke VII HIPIIS. Medan, 21.

Lindsay, H. E. (2003). Ecotourism: the Promise and Perils of Environmentally-Oriented Travel. Cambridge Scientific Abstracts. Available on-Line at Http:/Www. Csa. Com/Hottopics/Ecotour1/Oview. Html.

Nalayani, N. N. A. H. (2016). Evaluasi dan Strategi Pengembangan Desa Wisata di Kabupaten Badung, Bali. Jurnal Master Pariwisata (JUMPA).

Noor, M. (2011). Pemberdayaan masyarakat. CIVIS, 1(2/Juli).

Nugraheni, Y. L. K., Hartomo, D. O., \& Patworo, H. P. (2002). Analisis Pengaruh Faktor-Faktor Fundamental Perusahaan Terhadap Kelengkapan Laporan Keuangan. Jurnal Ekonomi Dan Bisnis (Dian Ekonomi), 8, 75-91.

Peraturan Menteri Lingkungan Hidup dan Kehutanan Nomor: P.83/MENLHK/SETJEN/KUM.1/10/2016 tentang Perhutanan Sosial.

[POKJA-PPS], 2017. Kelompok Kerja Percepatan Perhutanan Sosial Maluku Utara. Ternate

Purnomo, D. (2013). Modal Sosial dan Pemberdayaan Masyarakat Nelayan. Jurnal Fakultas Ilmu Sosial Dan Ilmu Politik Universitas Hasanuddin. Makassar.

Ramos, A. M., \& Prideaux, B. (2014). Indigenous ecotourism in the Mayan rainforest of Palenque: empowerment issues in sustainable development. Journal of Sustainable Tourism, 22(3), 461-479.

Rayes, M. L. (2007). Metode inventarisasi sumber daya lahan. Andi. Yogyakarta.

Suryani, A. (2014). Pendidikan Indonesia Menuju 2025: Permasalahan, Tantangan, dan Alternatif Kebijakan. Bandung: Remaja Rosdakarya.

Widayanti, S. (2012). Pemberdayaan Masyarakat: Pendekatan Teoritis. Welfare Jurnal Ilmu Kesejahteraan Sosial, 1(1). 